CASSOWARY volume 5 (1) Januari 2022: 11 - 21

ISSN : 2614-8900

E-ISSN : 2622-6545

Program Pascasarjana Universitas Papua, https://pasca.unipa.ac.id/

\title{
Pengaruh konsentrasi ekstrak bawang merah (Allium cepa L.) terhadap pertumbuhan setek nilam (Pogostemon cablin Benth.)
}

\author{
Hizbul Wathan ${ }^{1}$, Nurhayati ${ }^{1}$, Zuyasna $^{1}{ }^{*}$ \\ ${ }^{1}$ Program Studi AgroteknologiFakultas Pertanian, Universitas Syiah Kuala, \\ Jalan T.H. Krueng Kalee. No 3. Darussalam. Banda Aceh, 23111, Indonesia. \\ *Email: zuyasna@unsyiah.ac.id
}

Disubmit: 16 Spetember 2021, direvisi: 30 Desember 2021, diterima: 10 Januari 2022

Doi: https://doi.org/10.30862/casssowary.cs.v5.i1.117

\begin{abstract}
This study aims to determine the response to the use of varieties and concentrations of shallot extract and the interaction of these two factors on the variables of patchouli cuttings. This research has been carried out at the Experimental Garden of the Faculty of Agriculture and the Laboratory of Plant Physiology, Faculty of Agriculture Universitas Syiah Kuala, Banda Aceh. The research design used was a 2 x 5 factorial randomized block design (RAK). There were two factors studied, the patchouli variety (Tapak Tuan and Lhokseumawe) and the concentration of shallot extract with 5 levels $(0$, $15,30,45$ and $\left.60 \mathrm{ml} \mathrm{L}^{-1}\right)$. The data was analysed using ANOVA and followed by Tukey's HSD test (Tukey's Honestly Significant Difference Test) at the level 0.05\%. The results showed that the variety affected the number of leaves at 60 and 75 DAP, stem diameter at 75 and 90 DAP, number of shoots at 15, 45, 60 and 90 DAP and shoot height at 15 DAP. The best treatment was the Lhokseumawe variety at a concentration of $60 \mathrm{ml} \mathrm{L}^{-1}$ shallot extract. There was no interaction between the use of the two varieties and the concentration of shallot extract at all parameters of patchouli cuttings observed.
\end{abstract}

Keywords: cutting, Lhokseumawe, patchouli oil, perfume, Tapak tuan

\section{PENDAHULUAN}

Tanaman nilam (Pogostemon cablin Benth) merupakan tanaman yang dapat menghasilkan minyak atsiri atau yang lebih dikenal dengan nama patchouli oil. Minyak atsiri ini merupakan salah satu komoditi ekspor. Tingginya permintaan minyak atsiri ini merupakan peluang besar untuk mengembangkan tanaman nilam (Sabaruddin et al., 2020). Minyak nilam banyak digunakan dalam berbagai kegiatan industri, yaitu sebagai bahan campuran produk kosmetik, untuk kebutuhan farmasi, dan untuk pembuatan aroma terapi. Keunggulan minyak nilam dalam industri parfum yakni bersifat fiksatif yaitu kemampuannya dalam mengikat minyak lainnya sehingga harumnya dapat bertahan lama dan belum dapat dibuat secara sintetik hingga kini (Sagi et al., 2017).

Teknik budidaya tanaman nilam yang tepat dapat meningkatkan kualitas rendemen dan kualitas minyak yang 
bagus. Tanaman nilam telah dibudidayakan lebih dari 100 tahun di daerah penghasil utama yaitu Aceh dan Sumatera Utara, namun sampai sekarang kualitas rendemen dan mutu minyak yang dihasilkan masih rendah. Masalah ini disebabkan oleh beberapa faktor yaitu, teknologi budidaya yang masih sederhana, rendahnya mutu genetik tanaman, serta teknologi panen dan pasca panen yang kurang tepat (Hariyani et al., 2015). Varietas nilam di Indonesia terdapat 3 jenis, yang dibedakan berdasarkan karakter morfologi, kadar minyak serta ketahanan terhadap cekaman lingkungan biotik dan abiotiknya. Jenis nilam tersebut adalah nilam Aceh, nilam Jawa dan nilam sabun. Varietas unggul nilam yang dikembangkan dari nilam aceh (Pogostemon cablin Benth) adalah Tapak Tuan yang unggul dalam produksi dan kadar patchouli alcohol, Lhokseumawe dengan kadar minyaknya yang tinggi serta Sidikalang yang tahan terhadap penyakit layu bakteri dan nematoda (Noveriza et al., 2012).

Produksi nilam di Provinsi Aceh tahun 2015 adalah 645 ton, pada tahun 2016 mengalami penurunan produksi menjadi 466 ton, lalu pada tahun 2017 hampir sama dengan tahun sebelumnya yaitu 468 ton, selanjutnya di tahun 2018 mengalami penurunan drastis yaitu menjadi 178 ton dan pada tahun 2019 kembali mengalami kenaikan produksi menjadi 354 ton (Ditjenbun, 2020). Nilam umumnya diperbanyak dengan stek. Stek merupakan cara perbanyakan tanaman secara vegetatif buatan dengan menggunakan sebagian batang, cabang, akar, atau daun tanaman untuk ditumbuhkan menjadi tanaman baru (Mariana 2018)

Keuntungan perbanyakan dengan stek adalah tanaman baru yang diperoleh mempunyai sifat yang sama dengan induknya, umur seragam, dan waktu perbanyakan lebih singkat untuk memperoleh tanaman dalam jumlah banyak. Penanaman setek langsung di kebun menyebabkan pertumbuhan setek kurang baik serta tingkat kematian setek sangat tinggi dan memerlukan banyak bahan setek, sehingga untuk menghemat penggunaan bahan setek tersebut perlu dilakukan dengan cara pembibitan. Penggunaan bahan setek yang baik dapat mengoptimalkan pertumbuhan setek (Insan, 2013).

Permasalahan yang sering terjadi pada perbanyakan secara vegetative yaitu sulitnya pembentukan akar. Pembentukan akar dapat dipercepat dengan pemberian zat pengatur tumbuh (Martana et al., 2020). Penggunaan zat pengatur tumbuh dipengaruhi oleh jenis dan konsentrasi yang digunakan. Penggunaan konsentrasi zat pengatur tumbuh yang terlalu tinggi dapat menghambat pertumbuhan sedangkan konsentrasi yang terlalu rendah maka tidak efektif untuk memacu pertumbuhan (Rajiman, 2018). Hasil penelitian Muslimah et.al., (2018) menyatakan bahwa pemberian ekstrak bawang merah $15 \mathrm{ml} \mathrm{L}^{-1}$ air pada setek mucuna berpengaruh sangat nyata terhadap jumlah akar pada umur 60 HST serta berpengaruh nyata terhadap tinggi tunas pada umur 40 dan 60 HST.

Berdasarkanhasil penelitian tersebut dirasa perlu melakukan penelitian dengan perlakuan beberapa konsentrasi ekstrak bawang merah pada pembibitan dua varietas nilam dan melihat respon pertumbuhan bibitnya. Diharapkan dari penelitian ini dapat diketahui konsentrasi ekstrak bawang merah yang terbaik untuk pembibitan tanaman nilam.

Penelitian ini bertujuan untuk mengetahui respon penggunaan varietas dan konsentrasi zat pengatur tumbuh ekstrak bawang merah serta interaksi kedua faktor tersebut terhadap parameter setek nilam. 


\section{MATERI DAN METODE}

Penelitian ini dilaksanakan di Kebun Percobaan Fakultas Pertanian dan Laboratorium Fisiologi Tumbuhan Fakultas Pertanian Universitas Syiah Kuala, Banda Aceh.

Alat-alat yang digunakan dalam penelitian ini yaitu cangkul, parang, plastik transparan ukuran 3 meter, Paranet $70 \%$ berukuran $2 \mathrm{~m} \times 3 \mathrm{~m}$, juicer, ember, gelas ukur, ayakan 10 mesh, polybag dengan ukuran $29 \mathrm{~cm}$ x $30 \mathrm{~cm}$ kapasitas isi $3 \mathrm{~kg}$ sebanyak 120 buah, kayu balok, bambu, gembor, timbangan digital, meteran, kamera, kertas label dan perlengkapan alat tulis.

Bahan-bahan yang digunakan dalam penelitian ini yaitu tanaman nilam varietas Tapak Tuan dan varietas Lhokseumawe yang diperoleh dari Gampong Tuwi Eumpeuk Kecamatan Panga Kabupaten Aceh Jaya sebanyak 120 setek, bawang merah Aceh sebanyak $2 \mathrm{~kg}$, tanah sebanyak $240 \mathrm{~kg}$, pupuk kandang sebanyak $60 \mathrm{~kg}$, Insektisida Metomil 25\%, Fungisida Mankozeb $85 \%$ dan aquades.

Penelitian ini menggunakan Rancangan Acak Kelompok (RAK) pola Faktorial dengan dua faktor. Faktor pertama adalah varietas $(\mathrm{V})$ yang terdiri dari 2 taraf $(\mathrm{V} 1=$ varietas Tapak Tuan, $\mathrm{V} 2$ = varietas Lhokseumawe). Faktor kedua adalah konsentrasi ZPT ekstrak bawang merah yang terdiri dari 5 taraf $\left(\mathrm{K} 0=0 \mathrm{ml} \mathrm{L}^{-1}, \mathrm{~K} 1=15 \mathrm{ml} \mathrm{L}^{-1}, \mathrm{~K} 2=30\right.$ $\left.\mathrm{ml} \mathrm{L}{ }^{-1}, \mathrm{~K} 3=45 \mathrm{ml} \mathrm{L}^{-1}, \mathrm{~K} 4=60 \mathrm{ml} \mathrm{L}^{-1}\right)$.

Berdasarkan faktor percobaan yang digunakan terdapat 10 kombinasi perlakuan. Masing - masing perlakuan diulang sebanyak 3 kali dengan demikian penelitian ini memiliki 30 unit percobaan. Setiap unit percobaan diwakili oleh 3 tanaman, sehingga terdapat 90 unit percobaan.

Data hasil penelitian dianalisis menggunakan $F$ (ANOVA), apabila menunjukkan pengaruh yang nyata $(\alpha=$
5\%), maka dilakukan analisis lanjut menggunakan uji Beda Nyata Jujur (BNJ) pada taraf $5 \%$.

Lahan yang digunakan untuk penelitian terlebih dahulu dibersihkan dari gulma, kemudian dibuat naungan dengan menggunakan balok kayu dan ditutupi dengan paranet. Pembuatan naungan berfungsi untuk mengurangi proses penguapan pada fase pembibitan.

Media tanam yang digunakan adalah media tanam yang terdiri dari komposisi campuran tanah dan pupuk kandang dengan perbandingan 2:1. Selanjutnya tanah diayak menggunakan ayakan 10 mesh lalu dicampurkan dengan pupuk kandang dan dimasukkan ke dalam polybag berkapasitas $2 \mathrm{~kg}$.

Bahan setek dipotong sepanjang 4 ruas dan dimasukkan kedalam ember berisi air. Daun yang ada pada batang dipotong hingga menyisakan 2 atau 3 lembar daun untuk mengurangi transpirasi. Selanjutnya bahan setek dibungkus dengan pelepah batang pisang untuk menjaga kelembapan.

Umbi bawang merah dikupas dan dibersihkan kulitnya lalu dihaluskan menggunakan juicer. Umbi bawang merah yang telah halus kemudian disaring dan diperas hingga mendapatkan ekstrak bawang merah. Larutan hasil saringan diukur menggunakan gelas ukur sesuai konsentrasi perlakuan, selanjutnya dicukupkan volumenya dengan air aquades hingga mencapai 1 liter, lalu dimasukkan ke dalam wadah. Setek nilam direndam selama 10 menit sesuai masing masing perlakuan.

Sebelum bahan setek ditanam, media ditugal sedalam $5 \mathrm{~cm}$ panjang setek, kemudian tanah dipadatkan mengelilingi setek agar setek tidak roboh. Selanjutnya tanaman diberi sungkup untuk menjaga kelembapan dan memperkecil terjadinya proses penguapan. 
Pemeliharaan meliputi penyulaman, penyiraman, penyiangan dan pengen-dalian hama dan penyakit. Penyulaman dilakukan seminggu setelah tanam dengan tujuan untuk menggantikan tanaman yang mati, penyulaman dilakukan sebanyak 30\% dari jumlah bibit yang ditanam. Penyiraman dilakukan sebanyak dua kali sehari yaitu pada pagi dan sore hari. Penyiraman dilakukan sampai tanah pembibitan betul-betul basah dengan tujuan agar kelembaban tetap terjaga dan terpelihara. Penyiangan dilakukan secara fisik dengan cara mencabut gulma yang tumbuh di dalam polybag yang dilakukan 2 minggu sekali. Pengendalian hama dan penyakit dilakukan apabila tanaman terserang hama dan penyakit dengan menyemprotkan insektisida Metomil 25\% dengan konsentrasi $2 \mathrm{~g} \mathrm{~L}^{-1}$ air dan fungisida Mangkozeb $85 \%$ dengan konsentrasi $2 \mathrm{~g} \quad \mathrm{~L}^{-1}$ air disemprotkan pada umur 30 HST (hari setelah tanam).

Pengamatan dilakukan pada bibit setek tanaman nilam yang telah dikeluarkan dari sungkup pada umur 15 hari. Peubah pertumbuhan yang diamati antara lain: Jumlah tunas, tinggi tunas, diameter tunas, jumlah daun, volume akar, bobot berangkasan kering dan bobot berangkasan basah. Pengamatan dilakukan setelah 15 HST dengan interval 15 hari sekali sampai tanaman berumur 90 HST.

\section{HASIL DAN PEMBAHASAN}

\section{Pengaruh Perlakuan Varietas Terha- dap Pertumbuhan Setek Nilam}

\section{A. Jumlah daun (helai)}

Varietas berpengaruh nyata terhadap parameter jumlah daun setek nilam pada umur 60,75 , HST, namun berpengaruh tidak nyata terhadap jumlah daun setek nilam pada umur 15, 30, 45 dan 90 HST. Rata-rata jumlah daun setek nilam akibat perlakuan varietas dapat dilihat pada Tabel 1. Tabel tersebut menunjukkan jumlah daun setek nilam tertinggi dijumpai pada varietas Lhokseumawe pada umur 60 dan 75 HST yang berbeda nyata dengan varietas Tapak Tuan. Hal ini diduga adanya perbedaan sifat genetik yang dapat mempengaruhi daya adaptasi masingmasing varietas. Hal ini sejalan dengan hasil penelitian Faizin dan Susila (2018) dimana perbedaan pertumbuhan dipengaruhi oleh sumber bibit, perbedaan lingkungan dan perbedaan sifat genetik yang dibawa masing-masing asal sumber bibit yang dapat mempengaruhi kemampuan beradaptasi terhadap lingkungan.

\section{B. Diameter Batang}

Varietas berpengaruh sangat nyata terhadap parameter diameter batang setek nilam pada umur 60, 75, dan 90 HST, namun berpengaruh tidak nyata terhadap diameter batang setek nilam pada umur 15, 30 dan 45 HST. Rata-rata diameter batang setek nilam akibat perlakuan Varietas dapat dilihat pada Tabel 2. Tabel 2 menunjukkan diameter batang setek nilam yang tertinggi dijumpai pada varietas Lhokseumawe pada umur 60, 75 dan 90 HST yang berbeda nyata dengan varietas Tapak Tuan. Hal ini diduga karena adanya perbedaan sifat genetik dari masingmasing varietas unggul yang berbeda dari segi adaptasi tanaman lingkungan sehingga terdapat respons yang bervariasi. Menurut hasil penelitian Rahayu dan Harjoso (2011), pertumbuhan tanaman bukan hanya karena akibat pemberian pupuk tetapi varietas juga sangat berpengaruh, karena setiap varietas mempunyai sifat genetis, morfologis, maupun fisiologis yang berbeda-beda. Perbedaan varietas mempengaruhi perbedaan dalam hal keragaman penampilan tanaman. 
Tabel 1. Rata-rata jumlah daun setek nilam akibat perlakuan varietas nilam.

\begin{tabular}{lllllll}
\hline \multirow{2}{*}{ Varietas } & \multicolumn{5}{c}{ Diameter Batang $(\mathrm{mm})$} \\
& $15 \mathrm{HST}$ & $30 \mathrm{HST}$ & $45 \mathrm{HST}$ & $60 \mathrm{HST}$ & $75 \mathrm{HST}$ & $90 \mathrm{HST}$ \\
\hline Tapak Tuan $\left(\mathrm{V}_{1}\right)$ & 8,00 & 13,27 & 18,13 & $24,13 \mathrm{a}$ & $31,13 \mathrm{a}$ & 40,40 \\
Lhokseumawe $\left(\mathrm{V}_{2}\right)$ & 8,40 & 15,07 & 20,20 & $28,27 \mathrm{~b}$ & $36,00 \mathrm{~b}$ & 46,00 \\
BNJ 0,05 & - & - & - & 2,10 & 2,67 & - \\
\hline
\end{tabular}

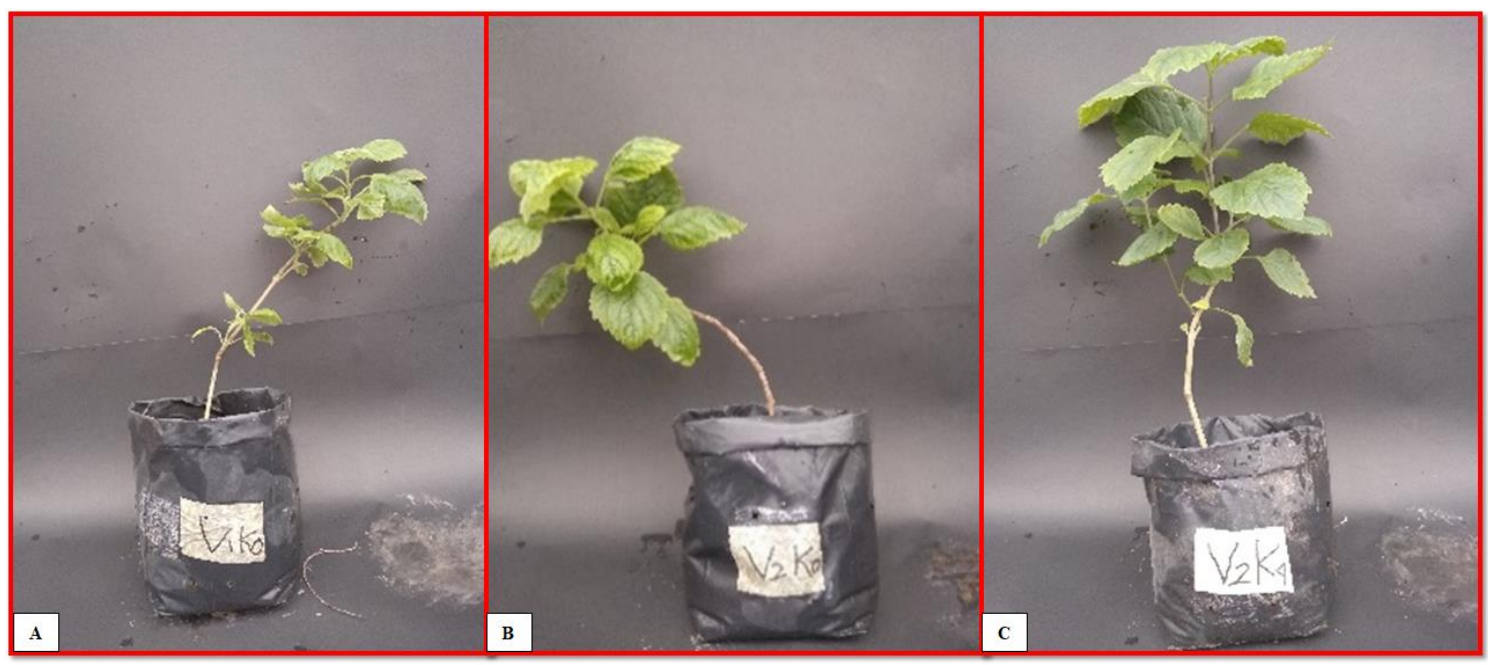

Gambar 1. Bibit tanaman nilam varietas Tapak tuan dan Lhokseumawe pada umur 90 HST. Varietas Tapak Tuan tanpa perlakuan pada umur 90 HST (A), Varietas Lhokseumawe tanpa perlakuan pada umur 90 HST (B), Varietas Lhokseumawe dengan perendaman ekstrak bawang merah $60 \mathrm{~m} \mathrm{~L}^{-1}$ pada umur 90 HST (C)

Tabel 2. Rata-rata diameter batang setek nilam akibat perlakuan varietas nilam.

\begin{tabular}{lllllll}
\hline \multirow{2}{*}{ Varietas } & \multicolumn{5}{c}{ Diameter Batang $(\mathrm{mm})$} \\
& $15 \mathrm{HST}$ & $30 \mathrm{HST}$ & 45 HST & 60 HST & 75 HST & $90 \mathrm{HST}$ \\
\hline Tapak Tuan $\left(\mathrm{V}_{1}\right)$ & 11,25 & 12,65 & 13,17 & $13,99 \mathrm{a}$ & $14,96 \mathrm{a}$ & $15,89 \mathrm{a}$ \\
Lhokseumawe $\left(\mathrm{V}_{2}\right)$ & 11,38 & 13,22 & 13,79 & $14,93 \mathrm{~b}$ & $16,14 \mathrm{~b}$ & $16,88 \mathrm{~b}$ \\
BNJ 0,05 & - & - & - & 0,32 & 0,34 & 0,33 \\
\hline
\end{tabular}

\section{Jumlah Cabang}

Varietas berpengaruh sangat nyata terhadap parameter jumlah cabang setek nilam pada umur $15,30,45,60$ dan 90 HST, namun berpengaruh tidak nyata terhadap jumlah cabang setek nilam pada umur 75 HST. Rata-rata jumlah cabang setek nilam akibat perlakuan Varietas dapat dilihat pada Tabel 3. Tabel tersebut menunjukkan jumlah cabang setek nilam yang tertinggi dijumpai pada varietas Lhokseumawe pada umur 15, 30, 45, 60 dan 90 HST yang berbeda nyata dengan varietas lainnya. Hal ini diduga karena setiap varietas memiliki daya adaptasi yang bebeda-beda. Hal ini sejalan dengan pendapat Marliah (2012) bahwa setiap varietas memiiki ketahanan yang berbeda, beberapa tanaman dapat melakukan adaptasi dengan cepat, namun sebaliknya ada tanaman yang membutuhkan waktu lama untuk dapat beradaptasi dengan lingkungan. Hal ini diaki batkan setiap varietas memiliki 
potensi genetik yang berbeda dalam merespon lingkungan tempat tumbuhnya.

\section{Tinggi Tunas}

Varietas berpengaruh sangat nyata terhadap parameter tinggi tunas setek nilam pada umur 15 HST, namun berpengaruh tidak nyata terhadap jumlah daun setek nilam pada umur 30, 45, 60, 75 dan 90 HST. Rata-rata jumlah daun setek nilam akibat perlakuan Varietas dapat dilihat pada Tabel 4 .

Tabel 4 menunjukkan tinggi tunas setek nilam yang tertinggi dijumpai pada varietas Lhokseumawe pada umur 15 HST yang berbeda nyata dengan varietas Tapak Tuan. Hal ini disebabkan karena perbedaan sifat genetik antar varietas serta daya adaptasi keduanya. Hal ini sejalan dengan pendapat Rosmiah (2018) bahwa setiap varietas mempunyai susunan genetik yang tidak sama dan kemampuan varietas itu sendiri dalam beradaptasi dengan lingkungan tumbuhnya, sehingga tetap menghasilkan pertumbuhan yang baik dan hasil yang maksimal.

\section{E. Bobot berangkasan kering, bobot berangkasan basah dan volume akar}

Varietas tidak berpengaruh nyata pada parameter bobot berangkasan basah, bobot berangkasan kering dan volume akar pada umur 90 HST. Rata-rata bobot berangkasan basah, bobot berangkasan kering dan volume akar pada setek nilam akibat perlakuan varietas dapat dilihat pada Tabel 5.

\section{Pengaruh konsentrasi ekstrak bawang merah terhadap pertumbu- han setek nilam.}

\section{A. Jumlah daun (helai)}

Konsentrasi berpengaruh sangat nyata terhadap parameter jumlah daun setek nilam pada umur 30, 60, HST dan berpengaruh nyata terhadap parameter jumlah daun setek nilam pada umur 75 dan 90 HST serta berpengaruh tidak nyata terhadap jumlah daun setek nilam pada umur 15 dan 45 HST. Rata-rata jumlah daun setek nilam akibat perlakuan konsentrasi dapat dilihat pada Tabel 6. Tabel tersebut menunjukkan rata rata jumlah daun setek nilam tertinggi dijumpai pada konsentrasi ekstrak bawang merah $45 \mathrm{ml} \mathrm{L}^{-1}$ pada umur 30 HST dan konsentrasi ekstrak bawang merah $60 \mathrm{ml} \mathrm{L}^{-1}$ pada umur 60, 75 dan 90 HST yang berbeda nyata dengan konsentrasi lainnya. Hal ini diduga bawang merah memiliki kandungan auksin yang berperan dalam pembentukan akar tanaman.

Tabel 3. Rata-rata jumlah cabang setek nilam akibat perlakuan varietas nilam.

\begin{tabular}{lllllll}
\hline \multirow{2}{*}{ Varietas } & \multicolumn{5}{c}{ Jumlah Cabang (Buah) } \\
& $15 \mathrm{HST}$ & $30 \mathrm{HST}$ & $45 \mathrm{HST}$ & $60 \mathrm{HST}$ & $75 \mathrm{HST}$ & $90 \mathrm{HST}$ \\
\hline Tapak Tuan $\left(\mathrm{V}_{1}\right)$ & $3,80 \mathrm{a}$ & $6,47 \mathrm{a}$ & $8,60 \mathrm{a}$ & $12,00 \mathrm{a}$ & 20,27 & $25,60 \mathrm{a}$ \\
Lhokseumawe $\left(\mathrm{V}_{2}\right)$ & $4,53 \mathrm{~b}$ & $6,80 \mathrm{ab}$ & $9,80 \mathrm{~b}$ & $14,07 \mathrm{~b}$ & 21,00 & $28,33 \mathrm{~b}$ \\
BNJ 0,05 & 0,32 & 0,35 & 0,30 & 0,32 & - & 0,54 \\
\hline
\end{tabular}

Tabel 4. Rata-rata tinggi tunas setek nilam akibat perlakuan varietas nilam

\begin{tabular}{lllllll}
\hline \multirow{2}{*}{ Varietas } & \multicolumn{7}{c}{ Tinggi Tunas $(\mathrm{cm})$} \\
& 15 HST & 30 HST & 45 HST & 60 HST & 75 HST & 90 HST \\
\hline Tapak Tuan $\left(\mathrm{V}_{1}\right)$ & $3.60 \mathrm{a}$ & 8.56 & 13.19 & 16.32 & 22.96 & 26.94 \\
Lhokseumawe $\left(\mathrm{V}_{2}\right)$ & $3.83 \mathrm{~b}$ & 8.90 & 13.78 & 17.59 & 23.55 & 27.41 \\
BNJ 0,05 & 0,08 & - & - & - & - & - \\
\hline
\end{tabular}


Akar yang terbentuk dengan baik pada tanaman akan membuat pertumbuhan organ tanaman lainnya juga tumbuh secara baik. Hal tersebut dikarenakan peranan akar yang sangat penting dalam menunjang perkemba-ngan organ lainnya seperti batang dan daun. Hal ini sesuai dengan Suyanti et al., (2013) menyatakan bahwa akar merupakan organ penyerap unsur hara dan air dari media tanam yang banyak mengandung bahan orga nik dan bahan anorganik. Bahan organik dan bahan anorganik ini sangat diperlukan oleh tumbuhan untuk mendukung pertumbuhan organ tanaman seperti akar, batang, dan daun. Menurut Martana et al., (2020) konsentrasi auksin yang tepat pada sel dapat meningkatkan tekanan osmotik, peningkatan permeabilitas sel sehingga dapat meningkatkan difusi masuknya air dan hara ke dalam sel. Dengan bertambahnya konsen trasi auksin dalam tubuh tanaman maka akan mengaktifkan pembentukan akar.

\section{B. Diameter batang (mm)}

Konsentrasi berpengaruh sangat nyata terhadap parameter diameter batang setek nilam pada umur $15,30,45$, 60, 75 dan 90 HST. Rata-rata diameter batang setek nilam akibat perlakuan konsentrasi dapat dilihat pada Tabel 7. Pada tabel tersebut, menunjukkan rata rata diameter batang setek nilam tertinggi dijumpai pada konsentrasi ekstrak bawang merah $45 \mathrm{ml} \mathrm{L}^{-1}$ pada umur 30, 60, 75 dan 90 HST dan konsentrasi $60 \mathrm{ml} \mathrm{L}^{-1}$ pada umur 15, 30 dan 45 HST yang berbeda nyata dengan perlakuan konsentrasi lainnya. Hal ini dikarenakan pada konsentrasi tersebut ekstrak bawang merah telah mampu merangsang pembentukan dan pertumbu-han akar pada stek tanaman nilam lebih baik sehingga menyebabkan tanaman mampu meningkatkan penyerapan unsur hara, air dan unsur lainnya, sehingga akan menghasilkan pertumbuhan tanaman yang lebih baik. Hal ini sesuai dengan pendapat Saidi (2018) bahwa perakaran tanaman yang lebih baik akan meningkatkan pertumbuhan dan perkembangan bagianbagian tanaman seperti tunas, batang dan daun yang selanjutnya akan dapat meningkatkan aktivitas fotosintesis.

Tabel 5. Rata-rata bobot berangkasan basah, bobot berangkasan kering dan volume akar.

\begin{tabular}{llll}
\hline Varietas & Berangkasan Basah & Berangkasan Kering & Volume Akar \\
\hline Tapak Tuan $\left(\mathrm{V}_{1}\right)$ & 19,07 & 9.58 & 61,40 \\
Lhokseumawe $\left(\mathrm{V}_{2}\right)$ & 20,38 & 9.58 & 61,50 \\
BNJ 0,05 & - & - & - \\
\hline
\end{tabular}

Tabel 6. Rata-rata jumlah daun setek nilam akibat perlakuan konsentrasi

\begin{tabular}{lllllll}
\hline \multirow{2}{*}{ Konsentrasi } & & \multicolumn{5}{c}{ Jumlah Daun (Helai) } \\
& $15 \mathrm{HST}$ & $30 \mathrm{HST}$ & $45 \mathrm{HST}$ & $60 \mathrm{HST}$ & $75 \mathrm{HST}$ & $90 \mathrm{HST}$ \\
\hline Kontrol $\left(\mathrm{K}_{0}\right)$ & 6,83 & $10,83 \mathrm{a}$ & 14,83 & $20,17 \mathrm{a}$ & $26,67 \mathrm{a}$ & $33,50 \mathrm{a}$ \\
$15 \mathrm{ml} \mathrm{L}^{-1}\left(\mathrm{~K}_{1}\right)$ & 8,50 & $13,00 \mathrm{~b}$ & 18,00 & $24,83 \mathrm{~b}$ & $33,17 \mathrm{bc}$ & $42,83 \mathrm{~b}$ \\
$30 \mathrm{ml} \mathrm{L}^{-1}\left(\mathrm{~K}_{2}\right)$ & 8,00 & $13,33 \mathrm{~b}$ & 18,17 & $25,33 \mathrm{~b}$ & $31,83 \mathrm{~b}$ & $40,33 \mathrm{~b}$ \\
$45 \mathrm{ml} \mathrm{L}^{-1}\left(\mathrm{~K}_{3}\right)$ & 8,17 & $17,50 \mathrm{c}$ & 23,17 & $29,17 \mathrm{c}$ & $36,33 \mathrm{~cd}$ & $46,17 \mathrm{~b}$ \\
$60 \mathrm{ml} \mathrm{L}^{-1}\left(\mathrm{~K}_{4}\right)$ & 9,50 & $16,17 \mathrm{c}$ & 21,67 & $31,50 \mathrm{c}$ & $39,83 \mathrm{~d}$ & $53,17 \mathrm{c}$ \\
BNJ 0,05 & - & 1,90 & - & 3,32 & 4,22 & 6,16 \\
\hline
\end{tabular}




\section{Jumlah cabang}

Konsentrasi berpengaruh sangat nyata terhadap parameter jumlah cabang setek nilam pada umur $15,30,45,60,75$ dan 90 HST. Rata-rata jumlah cabang setek nilam akibat perlakuan konsentrasi dapat dilihat pada Tabel 8. Data yang tertera pada Tabel 8 menunjukkan rata rata jumlah cabang setek nilam tertinggi dijumpai pada konsentrasi $60 \mathrm{ml} \mathrm{L}^{-1}$ pada umur 15, 30, 45, 60, 75 dan $90 \mathrm{HST}$ yang berbeda nyata dengan perlakuan konsen-trasi lainnya. Hal ini diduga zat pengatur tumbuh yang terkandung di dalam ekstrak bawang merah mengandung auksin yang dapat mempercepat proses fisiologis tanaman sehingga terbentuknya tunas pada setek. Muslimah et al., (2018) menyatakan auksin yang diserap oleh jaringan tanaman akan mengaktifkan ener-gi cadangan makanan dan meningkatkan pembelahan sel, pemanjangan dan differensiasi sel yang pada akhirnya membentuk tunas dan proses pemanjangan tunas. Hasil penelitian Ariska et al., (2020) pemberian ekstrak bawang merah pada setek tanaman lada berbeda nyata terhadap jumlah tunas pada umur 30,45 dan 60 HST.

\section{Tinggi Tunas}

Konsentrasi berpengaruh sangat nyata terhadap parameter tinggi tunas setek nilam pada umur 15, 30, 45, 60, 75 dan 90 HST. Rata-rata tinggi tunas setek nilam akibat perlakuan konsentrasi dapat dilihat pada Tabel 9. Data pada tabel ini menunjukkan rata rata jumlah tunas setek nilam tertinggi dijumpai pada konsentrasi $60 \mathrm{ml} \mathrm{L}^{-1}$ pada umur 15, 30, 45, 60, 75 dan 90 HST yang berbeda nyata dengan perlakuan konsentrasi lainnya. Hal ini diduga bahan setek pucuk yang digunakan masih mengandung zat auksin yang dapat merangsang pembentukan akar dan tunas. Menurut Faizin (2016) bahwa pada bahan stek yang masih terdapat daun sebagai sumber karbohidrat dan auksin, serta masih aktifnya daun untuk berfotosintesis akan dapat merangsang pertumbuhan akar dan tunas yang lebih baik, sehingga pertumbuhan stek dapat berlangsung dengan baik. Selain itu juga karena kandungan auksin pada setek pucuk lebih tinggi dibandingkan dengan bagian dibawahnya karena auksin endogen suatu tanaman diproduksi dari jaringan meristem dan menyebabkan adanya dominansi apikal.

\section{E. Bobot berangkasan basah, bobot berangkasan kering dan volume akar}

Konsentrasi tidak berpengaruh nyata pada parameter bobot berangkasan basah, bobot berangkasan kering dan volume akar pada umur 90 HST. Ratarata bobot berangkasan basah, bobot berangkasan kering dan volume akar pada setek nilam akibat perlakuan konsentrasi dapat dilihat pada Tabel 10. Data yang disajikan pada tabel tersebut menunjukkan rata rata bobot berangkasan basah dan bobot berangkasan kering yang cenderung tertinggi dijumpai pada perlakuan $45 \mathrm{ml}$ $\mathrm{L}^{-1}$ walaupun secara statistik berbeda tidak nyata dengan perlakuan lainnya. Rata-rata volume akar yang cenderung tertinggi dijumpai pada perlakuan konsentrasi $60 \mathrm{ml} \mathrm{L}^{-1}$ walaupun secara statistik berbeda tidak nyata dengan perlakuan lainnya. 
Tabel 7. Rata-rata diameter batang setek nilam akibat perlakuan konsentrasi.

\begin{tabular}{lllllll}
\hline \multirow{2}{*}{ Konsentrasi } & \multicolumn{5}{c}{ Jumlah Daun (Helai) } \\
& $15 \mathrm{HST}$ & $30 \mathrm{HST}$ & $45 \mathrm{HST}$ & $60 \mathrm{HST}$ & $75 \mathrm{HST}$ & $90 \mathrm{HST}$ \\
\hline Kontrol (K0) & $10,63 \mathrm{a}$ & $11,46 \mathrm{a}$ & $12,20 \mathrm{a}$ & $12,81 \mathrm{a}$ & $13,90 \mathrm{a}$ & $14,48 \mathrm{a}$ \\
$15 \mathrm{ml} \mathrm{L}-1$ (K1) & $10,57 \mathrm{a}$ & $13,01 \mathrm{~b}$ & $13,96 \mathrm{a}$ & $14,80 \mathrm{c}$ & $16,30 \mathrm{c}$ & $17,35 \mathrm{c}$ \\
$30 \mathrm{ml} \mathrm{L}-1(\mathrm{~K} 2)$ & $11,28 \mathrm{~b}$ & $12,44 \mathrm{~b}$ & $12,54 \mathrm{~b}$ & $13,79 \mathrm{~b}$ & $14,87 \mathrm{~b}$ & $15,75 \mathrm{~b}$ \\
$45 \mathrm{ml} \mathrm{L}-1$ (K3) & $11,56 \mathrm{~b}$ & $13,88 \mathrm{c}$ & $14,12 \mathrm{~b}$ & $15,58 \mathrm{~d}$ & $16,36 \mathrm{c}$ & $17,20 \mathrm{c}$ \\
$60 \mathrm{ml} \mathrm{L}-1(\mathrm{~K} 4)$ & $12,54 \mathrm{c}$ & $13,88 \mathrm{c}$ & $14,59 \mathrm{~b}$ & $15,31 \mathrm{~cd}$ & $16,33 \mathrm{c}$ & $17,13 \mathrm{c}$ \\
BNJ 0,05 & 0,62 & 0,78 & 0,72 & 0,50 & 0,34 & 0,52 \\
\hline
\end{tabular}

Tabel 8. Rata-rata jumlah cabang setek nilam akibat perlakuan konsentrasi.

\begin{tabular}{lllllll}
\hline \multirow{2}{*}{ Konsentrasi } & \multicolumn{5}{c}{ Jumlah Daun (Helai) } \\
& $15 \mathrm{HST}$ & $30 \mathrm{HST}$ & $45 \mathrm{HST}$ & $60 \mathrm{HST}$ & $75 \mathrm{HST}$ & $90 \mathrm{HST}$ \\
\hline Kontrol $\left(\mathrm{K}_{0}\right)$ & $3,33 \mathrm{a}$ & $4,50 \mathrm{a}$ & $6,67 \mathrm{a}$ & $9,50 \mathrm{a}$ & $15,17 \mathrm{a}$ & $20,17 \mathrm{a}$ \\
$15 \mathrm{ml} \mathrm{L}-1\left(\mathrm{~K}_{1}\right)$ & $4,34 \mathrm{~b}$ & $5,67 \mathrm{~b}$ & $8,33 \mathrm{~b}$ & $11,50 \mathrm{~b}$ & $17,67 \mathrm{~b}$ & $23,66 \mathrm{~b}$ \\
$30 \mathrm{ml} \mathrm{L}-1\left(\mathrm{~K}_{2}\right)$ & $4,17 \mathrm{~b}$ & $6,33 \mathrm{c}$ & $9,00 \mathrm{c}$ & $13,50 \mathrm{c}$ & $21,01 \mathrm{c}$ & $27,34 \mathrm{c}$ \\
$45 \mathrm{ml} \mathrm{L}-1\left(\mathrm{~K}_{3}\right)$ & $4,00 \mathrm{~b}$ & $6,67 \mathrm{c}$ & $9,34 \mathrm{c}$ & $14,34 \mathrm{~d}$ & $23,67 \mathrm{~d}$ & $29,01 \mathrm{~d}$ \\
$60 \mathrm{ml} \mathrm{L}-1\left(\mathrm{~K}_{4}\right)$ & $5,00 \mathrm{c}$ & $10,00 \mathrm{~d}$ & $12,66 \mathrm{~d}$ & $16,33 \mathrm{e}$ & $25,67 \mathrm{e}$ & $34,67 \mathrm{e}$ \\
BNJ 0,05 & 0,51 & 0,56 & 0,48 & 0,77 & 0,74 & 0,85 \\
\hline
\end{tabular}

Tabel 9. Rata-rata tinggi tunas setek nilam akibat perlakuan konsentrasi

\begin{tabular}{lllllll}
\hline \multirow{2}{*}{ Konsentrasi } & \multicolumn{7}{c}{ Jumlah Daun (Helai) } \\
& 15 HST & $30 \mathrm{HST}$ & $45 \mathrm{HST}$ & $60 \mathrm{HST}$ & $75 \mathrm{HST}$ & $90 \mathrm{HST}$ \\
\hline Kontrol (K0) & $3,39 \mathrm{a}$ & $7,02 \mathrm{a}$ & $11,62 \mathrm{a}$ & $13,87 \mathrm{a}$ & $19,70 \mathrm{a}$ & $22,33 \mathrm{a}$ \\
$15 \mathrm{ml} \mathrm{L}-1$ (K1) & $3,67 \mathrm{~b}$ & $8,49 \mathrm{~b}$ & $12,43 \mathrm{~b}$ & $15,97 \mathrm{~b}$ & $21,86 \mathrm{~b}$ & $25,94 \mathrm{~b}$ \\
$30 \mathrm{ml} \mathrm{L}-1(\mathrm{~K} 2)$ & $3,62 \mathrm{~b}$ & $8,78 \mathrm{~b}$ & $12,85 \mathrm{bc}$ & $15,96 \mathrm{~b}$ & $22,39 \mathrm{bc}$ & $26,96 \mathrm{~b}$ \\
$45 \mathrm{ml} \mathrm{L}-1$ (K3) & $3,87 \mathrm{c}$ & $9,34 \mathrm{c}$ & $13,27 \mathrm{c}$ & $18,09 \mathrm{c}$ & $23,57 \mathrm{c}$ & $27,49 \mathrm{~b}$ \\
$60 \mathrm{ml} \mathrm{L}-1(\mathrm{~K} 4)$ & $4,03 \mathrm{~d}$ & $10,04 \mathrm{~d}$ & $17,28 \mathrm{~d}$ & $20,88 \mathrm{~d}$ & $28,76 \mathrm{~d}$ & $33,19 \mathrm{c}$ \\
BNJ 0,05 & 0,13 & 0,47 & 0,72 & 1,35 & 1,31 & 1,89 \\
\hline
\end{tabular}

Tabel 10. Rata-rata bobot berangkasan basah, bobot berangkasan kering dan volume akar

\begin{tabular}{llll}
\hline Konsentrasi & Berangkasan Basah & Berangkasan Kering & Volume Akar \\
\hline Kontrol (K0) & 16,54 & 10,20 & 60,00 \\
15 ml L-1 (K1) & 18,53 & 9,67 & 60,75 \\
$30 \mathrm{ml} \mathrm{L}-1(\mathrm{~K} 2)$ & 20,13 & 8,57 & 61,50 \\
$45 \mathrm{ml} \mathrm{L}-1(\mathrm{~K} 3)$ & 23,31 & 10,30 & 61,50 \\
$60 \mathrm{ml} \mathrm{L}-1(\mathrm{~K} 4)$ & 20,12 & 9,16 & 63,50 \\
BNJ 0,05 & - & - & - \\
\hline
\end{tabular}

Pengaruh Interaksi Antara Varietas

Dan Konsentrasi Ekstrak Bawang Merah Terhadap Pertumbuhan Setek Nilam.

Hasil uji F menunjukkan bahwa terdapat interaksi yang berbeda tidak nyata antara penggunaan dua varietas dan konsentrasi ekstrak bawang merah terhadap semua parameter setek nilam yang diamati.

\section{KESIMPULAN}

Pertumbuhan setek nilam Varietas Lhokseumawe dengan menggunakan konsentrasi ekstrak bawang merah $60 \mathrm{ml}$ $\mathrm{L}^{-1}$ lebih baik dibandingkan Varietas Tapak Tuan. Konsentrasi ekstrak 
bawang merah terbaik untuk menginduksi pertumbuhan setek nilam adalah $60 \mathrm{ml} \mathrm{L}^{-1}$.

\section{DAFTAR PUSTAKA}

Ariska, N., Fitri, S., \& Fajri, L. (2020). Pengaruh Jenis Dan Konsentrasi Zpt Alami Terhadap Pertumbuhan Stek Lada (Piper nigrum L.). 6(1):16-27.

Faizin, R. (2016). Pengaruh Jenis Setek dan Konsentrasi Zat Pengatr Tumbuh Growtone Terhadap Pertumbuhan Tanaman Nilam (Pogestemon cablin Benth). Jurnal Agrotek Lestari, 2(1): 39-50.

Faizin, R., \& Susila, P. (2018). Respon Naungan Terhadap Pertumbuhan Dua Varietas Nilam (Pogostemon cablin Benth.). Jurnal Agrium, 15(2): 83-90.

Hariyani, Widaryanto, E., \& Herlina, N. (2015). Pengaruh Umur Panen Terhadap Rendemen dan Kualitas Minyak Atsiri Tanaman Nilam ( Pogostemon cablin Benth .) The Influence Of Age Harvest On Yield And An Essential Oil Quality of Patchouli (Pogostemon cablin Benth .). Jurnal Produksi Tanaman, 3(3):205-211.

Hayati, M., Hayati, E., \& Denni, D. (2011). Pengaruh pupuk organik dan anorganik terhadap pertumbuhan beberapa varietas jagung manis di lahan tsunami. Jurnal Floratek, 6(1):7483.

Insan W. 2013. Respon Pertumbuhan Bibit Stek Nilam (Pogostemon cablin Benth) Dengan Perlakuan Jumlah Ruas Dan Komposisi Media Tanam. Jurnal Penelitian Ilmu Pertanian. 2(2):2-22.

Mariana, M. (2017) Pengaruh Media Tanam Terhadap Pertumbuhan Stek Batang Nilam (Pogostemon cablin Benth). Agrica Ekstensia, 11(1): 1-8.

Martana, S. B., Sofyadi, E., \& Widyastuti L., S. N. (2020). Pertumbuhan Tunas Dan Akar Setek Tanaman Mawar (Rosa sp.) Akibat Konsentrasi Air Kelapa. Paspalum: Jurnal Ilmiah Pertanian, 8(1):31-36

Marliah, A., Hayati, M., \& Muliansyah, I. (2012). Pemanfaatan Pupuk Organik Cair Terhadap Pertumbuhan Dan Hasil Beberapa Varietas Tomat (Lycopersicum esculentum L.). Jurnal Agrista, 16(3):122-128.

Muslimah, Y., Jalil, M., Hadianto, W.H, Sarwanidas, T, \& Hasan, A. (2018). Pengaruh Konsentrasi Ekstrak Bawang Merah dan Media Tanam Terhadap Pertumbuhan setek Mucuna ( Mucuna bracteate). Jurnal Agrotek Lestari, 1(1): 47-54

Noveriza, R., Suastika, G., Hidayat, S. H., \& Kartosuwondo, U. (2012). Potyvirus associated with mosaic disease on patchouli (Pogostemon cablin (Blanco) Benth.) plants in Indonesia. Journal of ISSAAS (International Society for Southeast Asian Agricultural Sciences), 18(1):131-146.

Rajiman, R. (2018). Pengaruh Zat Pengatur Tumbuh (ZPT) Alami Terhadap Hasil Dan Kualitas Bawang Merah. Prosiding Seminar Nasional Fakultas Pertanian UNS, 2(1): A.327335

Rahayu, A. Y., \& Harjoso, T. (2011). Aplikasi Abu Sekam pada Padi Gogo (Oryza sativa L.) terhadap Kandungan Silikat dan Prolin Daun serta Amilosa dan Protein Biji. Biota: Jurnal Ilmiah IlmuIlmu Hayati, 16(1):48-55.

Rosmiah, R., \& Saputri, I. F. (2018). Uji Beberapa Varietas Jagung Manis 
(Zea Mays Saccharata Sturt) di Lahan Lebak. Klorofil: Jurnal Penelitian Ilmu-Ilmu Pertanian, 13(1):50-53.

Sabaruddin, S., Millang, S., Bachtiar, B., \& Samsu, A. K. A. (2020). Pengaruh Naungan Kayu Kuku (Pericorpsis Mooniana Thw) Terhadap Pertumbuhan Dan Biomassa Nilam (Pogestemon cablin Benth) Pada Sistem Agroforestry Di Kabupaten Kolaka Sulawesi Tenggara. Jurnal Eboni, 2(1): 39-44.

Sagi, F. N., Bagu, F. S., \& Pembengo, W. (2017). Pengaruh umur panen dan waktu penjemuran terhadap rendemen minyak nilam (Pogostemon cablin Benth) varietas Sidikalang. Jatt, 6(1): 5660

Saidi, A. B. (2018). Pengaruh Konsentrasi Dan Lama Perendaman Rootone F Terhadap Pertumbuhan Stek Nilam (Pogostemon cablin Benth.). Jurnal Agrotek Lestari, 3(2):19-30

Suyanti, M., \& Linda, R. (2013). Respon pertumbuhan stek pucuk keji beling (Strobilanthes crispus $\mathrm{Bl}$ ) dengan pemberian IBA (Indole Butyric Acid). Protobiont, 2(2):28-30 